\title{
THE EUROPEAN CENTRAL BANK'S COMMUNICATION AT THE TIMES OF MARIO DRAGHI
}

by Jacques Ziller

The three articles that are published after this short introduction in the Journal "Il Politico" are some of the products of a workshop on "An Interdisciplinary Analysis of the European Central Bank's Communication: An Instrument of Monetary Policy and a Vector of Accountability", which has been organised in the framework of the Research project of National Interest (PRIN) (2012sam3km) on EU procedures, held at the University of Pavia on 30 May 2016. The idea of the workshop was generated in the first instance by the announcement of 26 July 2012 by Mario Draghi that the ECB would do "whatever it takes" to preserve the euro, followed by the publication of a press release regarding the elements of the Outright Monetary Transactions program that the ЕСB announced it might put in place it became necessary. Eight years have elapsed since that famous announcement and Mario Draghi has finished his mandate and been replaced by Christine Lagarde. The polemics that have been generated by her announcements just after the World Health Organisation had announced that it had made the assessment that COVID-19 could be characterized as a pandemic tragically show that the importance of communication remains, not only as an instrument of monetary policy, but as an instrument in politics, going back to the ECB's Communication at the Times of Mario Draghi.

Before Draghi's announcements, there was little attention from legal scholarship to the work of central banks - apart from specialists of banking law - let alone to the communication of central banks. Indeed, that type of communication did not enter neither in the categories

\section{Professor of European Union Law, University of Pavia.}


of "hard law" i.e. binding legal instruments such as legislation, regulations, single case decisions of public authorities, contracts or court rulings. It did not either enter in the category of "soft law" i.e. nonbinding instruments that can eventually affect the legal position of natural or legal persons. The immediate impact on the markets of Draghi's declaration and of the general indications published on the ECB's website started attracting attention of practice and the scholars. Indeed, in early 2014, the German Federal Constitutional Court accepted an appeal against such a plan and made a preliminary reference to the European Court of Justice as to its legitimacy. The EU Court has responded -not finding any illegality -but at the time of the Workshop the German Court had not yet ruled on the merits. The point that at first attracted the interest of lawyers is that a simple press release announcing possible action had been considered as producing effects such that there could be individuals with standing to initiate proceedings before a court. A closer look showed -as is well known by specialists who are knowledgeable of central banks' workings -that not only the ЕСВ but also others -such as the us Federal Reserve -have developed an elaborate communication policy -including the use of silence -as a monetary policy instrument. The controversies generated by the ECB'S communication in the context of the financial crisis and sovereign debt crisis have moreover highlighted that communication is also the main vector of accountability for an independent central bank with respect to both Parliament and the citizens.

As a scholar who was accustomed to work together with economists, political scientists, and sociologists, I thought it worthwhile to focus on the communication of the ECB from a scientific perspective, with a multidisciplinary approach. The workshop indeed fostered exchanges of views among practitioners from central banks and academics, and among economists, lawyers and political scientists, as specialists of communication theory and practice. The three papers published here ${ }^{1}$ are reflecting that work: Allegra Canepa looks at "Unconventional Monetary Policies and Communication Strategies of the ECB" mainly with the eyes of a legal scholar using not only legal literature but also economic and social scientists work. Thierry Bracke,

1 In "Il Politico", n. 1, 2020, pp. 67-121. 
who has been Deputy Director General Communications of the ECB since July 2013 demonstrates how a practitioner educated in economics can master typical political science analyses through his reflections on "Central Bank Communication in the Past Two Decades". The same is characteristic of Alessandro Giovannini and Jean-François Jamet's "Matching Accountability with Independence". Both their articles also show how important the legal framework is for a central bank's communication.

Riassunto - In un periodo in cui le dichiarazioni della neopresidente della BCE Christine Lagarde, durante l'emergenza sanitaria generata dall'epidemia di coronavirus, hanno scatenato polemiche, può essere utile tornare con analisi multidisciplinari sulla comunicazione della BCE ai tempi di Mario Draghi, come fanno i tre articoli di seguito pubblicati in questo numero della rivista "Il Politico". 